\title{
Elementary school students' experiences of writing difficulties
}

\author{
Débora Cecílio Fernandes' \\ Central-West State University, PR, Brazil \\ Selma de Cássia Martinelli \\ State University of Campinas, SP, Brazil
}

\begin{abstract}
The aim of this research was to assess and to analyze the main writing difficulties presented by second to fifth graders of the elementary school, using Rasch model. Some 4I 3 students from public schools participated, from which 227 (55\%) were female. Participants were assessed with Writing Assessment Test, in the syllable, word and pseudoword subtests. Data were analyzed by the Rasch Model. It was verified that more complex structured syllables as consonant-consonant-vogal-consonant were the most difficult. The most difficult words had phonemes that could possibly be represented by more than one grapheme and had accent. In the more difficult pseudowords it was necessary to use well defined orthographic rules, like " $m$ " before " $p$ " and "b". Obtained results can help teachers to anticipate probable student difficulties and to plan differentiated educational strategies.
\end{abstract}

Keywords: orthography; writing; assessment; Rasch model; elementary school.

\section{DIFICULDADES DE ESCRITA EM ALUNOS DO ENSINO FUNDAMENTAL}

Resumo: $O$ objetivo da presente pesquisa foi avaliar e analisar as principais dificuldades de escrita apresentadas por alunos do $2^{\circ}$ ao $5^{\circ}$ ano do Ensino Fundamental, utilizando o modelo de Rasch. Participaram da pesquisa 4 I 3 alunos de escolas públicas, sendo 227 (55\%) do sexo feminino. Os participantes foram avaliados com o Teste de Avaliação da Escrita, nos subtestes sílabas, palavras e pseudopalavras. Os dados foram analisados a partir do modelo de Rasch. Verificou-se que sílabas com estrutura mais complexa como consoante-consoante-vogal-consoante foram mais difíceis. As palavras mais difíceis apresentaram a possibilidade de um fonema ser representado por mais de um grafema e continham acento. Nas pseudopalavras mais difíceis era necessário empregar regras ortográficas bem definidas como o uso do "m" antes de "p" e "b". Os resultados obtidos podem auxiliar o professor a antecipar as prováveis dificuldades dos alunos e planejar estratégias pedagógicas diferenciadas.

Palavras-chave: ortografia; escrita; avaliação; modelo de Rasch; ensino fundamental.

\section{DIFICULTADES DE ESCRITURA EM ALUMNOS DE LA ENSEÑANZA BÁSICA}

Resumen: El objetivo de la presente investigación fue evaluar y analizar las principales dificultades de escritura presentadas por alumnos del segundo al quinto curso de la Enseñanza Básica, mediante el uso del modelo de Rasch. Participaron 4 I 3 alumnos de escuelas públicas, siendo que 227 (55\%) eran del sexo femenino. A los participantes se

1 Mailing address: Débora Cecílio Fernandes: Rua Bauru, 2399, Bairro Boqueirão, Guarapuava, Paraná, Brazil. CEP: 85022-330. E-mail: debora.cecilio@gmail.com 


\begin{abstract}
les evaluó con el Test de Evaluación de la Escritura, en los subtests de sílabas, palabras y pseudopalabras. Se verificó que las sílabas con estructura más compleja como consonante-consonante-vocal-consonante fueron las más difíciles. Las palabras más difíciles presentaron la posibilidad de un fonema ser representado por más de un grafema y contenían tilde. En las pseudopalabras más difíciles era necesario emplear el uso de reglas ortográficas bien definidas como el uso de la " $m$ " antes de la " $p$ " y "b". Los resultados obtenidos pueden auxiliar el profesor a anticipar las probables dificultades de los alumnos y planear estrategias pedagógicas diferenciadas.
\end{abstract}

Palabras clave: ortografía; escritura; evaluación; modelo de Rasch; enseñanza básica.

\title{
Introduction
}

Writing is a very complex system of symbolic acquisition that involves several cognitive processes (Capovilla, Gutschow, \& Capovilla, 2004; Vega Cuetos, Sánchez Ramos, \& Hernández Ruano, 2002), whether it is the writing of an isolated word or more intricate elaborations such as the construction of texts. Additionally, the acquisition of writing is slow and difficult, requiring years of effort on the part of students.

In this context, various studies conducted by Berninger, among them being Abbott and Berninger (1993), support a theoretical reading and writing model in which writing processes involve stages from the generation of ideas of what one intends to write, the transformation of such ideas in a representation of language (words, phrases, and speech), going through transcription and up to the generation of texts (or words, phrases or speech). The transcription process refers to the combination of orthographic knowledge with motor movements necessary to produce letters and words. The author also highlights the role of executive functions and working memory.

Specifically in the case of the Portuguese language spoken in Brazil, several authors, including Faraco (2016), Morais and Rios Leite (2012), and Lemle (2009), suggest there are various specificities that should be taken into account in the acquisition of written language. In this alphabetic system, some phonemes can be represented in more than one way and some graphemes represent more than one sound. Writing has several linguistic, special and temporal properties, such as the relationship between letters and sounds (a letter may represent one or various sounds and one sound may be represented by different letters); the quantitative correspondence between letters and sounds (each word is written with a given number of letters, which do not always correspond to the number of phonemes that form it); variations between the way words are pronounced and the way words are spelled; variations in the position of each letter in the graphic space and in the direction of writing; in the linearity (one letter is written after another); and segmentation (pauses accruing from the discontinuous nature of writing).

Therefore, orthography plays an important role in this notation system, as it systematizes the way each word is written in Portuguese. Even though the alphabet has a limited number of letters and signs and orthographic norms regulates this system, mastering this notation system has proven to be a much more complex task than one 
might suppose (Nunes and Bryant, 2014), which has motivated researchers to conduct studies to analyze and intervene in children's writing (Zorzi, 1998; Santos \& Maluf, 2010; Batista \& Capellini, 2011; Capellini, et al., 2011; Rosa Neto, Xavier, \& Santos, 2013; Caliatto \& Fernandes, 2014), among other topics of study.

This study's objective was to investigate the writing performance of students using the Teste de Avaliação da Escrita [Writing Skills Assessment] (Martinelli et. al., 2015). This instrument was developed to assess the writing of syllables, words, pseudowords, phrases, and the textual production of elementary school students. Therefore, this study was intended to perform an initial exploration of this instrument and investigate the performance of students. Thus, the objective was to assess and analyze the main writing difficulties experienced by students attending from the 2 nd to the 5 th grades using the Rasch model.

\section{Method}

\section{Participants}

413 elementary school students took part in this study; $227(55 \%)$ were girls. The students were attending the 2 nd, 3rd, 4th and 5th grades of two public schools located in a city in the interior of the state of São Paulo, Brazil. Of the total number of children, $65(15.7 \%)$ were in the 2 nd grade, $112(27.1 \%)$ in the 3rd grade, $139(33.7 \%)$ in the 4 th, and 97 (23.5\%) were in 5th grade.

\section{Instruments}

Teste de Avaliação da Escrita -TAE [Writing Skills Assessment] (Martinelli et al, 2015): TAE was developed considering knowledge accumulated by research in the field of Cognitive Psychology, more specifically, knowledge concerning aspects present in the alphabetical writing system and those related to coding processes, the planning of ideas, and the composition of texts, such as those previously mentioned. This instrument is composed of subtests addressing the dictation of syllables, words, pseudowords, phrases, and writing composition. It allows certain writing aspects to be assessed, such as regular and irregular orthography, orthographic rules, rules for punctuation and the use of diacritics, in addition to the use of capital letters and the composition of a narrative text. The entire test is contextualized around a video-recorded story, the plot of which is a regular day at school. The video lasts 1.5 minutes and is presented to the students at the beginning of the test.

The instrument's writing activities are based on the elements presented in the children's story. The first activity refers to the writing of 17 dictated syllables, which addressed the following syllabic structures: consonant-vowel (cv), vowel-consonant (vc), consonant-consonant-vowel (ccv), consonant-vowel-vowel (cvv), consonant-vowelvowel-consonant (cvvc), consonant-consonant-vowel-consonant (ccvc), consonantconsonant-vowel-vowel-consonant (ccvvc). The purpose of this activity was to assess coding rules by using phoneme-grapheme representation (e.g., ta, noi, bli, guas). 
The words subtest is composed of 25 items and includes words with regular and irregular orthography, in addition to words that must comply with orthographic rules, as well as the use of diacritics (e.g., sala [room], mochila [backpack], roupa [clothing], gargalhada [laugh], carteira [wallet]). Seventeen pseudowords requiring the use of orthographic rules are dictated in the third subtest (e.g., quentico, lequipa, teneda, gutapoca, forinfura).

Afterwards, the students were asked to write a total of six dictated phrases (e.g., Os alunos gostaram da atividade [The students liked the activity], A aula mais interessante aconteceu no pátio da escola [The most interesting class happened in the school yard]). The instrument's final stages include activities addressing writing composition skills. In the first composition task, the student is supposed to write phrases based on a scene from the story (a total of three phrases); in the last activity, students are supposed to write a brief text for the end of the story. For this study's purposes, the spelling of syllables, words and pseudowords were analyzed.

The analysis of the instrument, according to the Rasch model (1960), revealed that the psychometric properties of the subtests concerning the dictation of syllables, words, and pseudowords were satisfactory, indicating its applicability to assess the skills of children. The syllables subtest obtained an infit mean of 1.00 and outfit mean of 1.06, which are considered appropriate fit (Linacre, 2009). The highest infit index was 1.23 and the highest outfit was 1.67, while none of them represent any discrepancy that should be of concern. The items' reliability index was quite high, at 0.99.

The words subtest also presented satisfactory results. The infit mean was 1.00 $(S D=0.13)$ and outfit was $1.25(S D=1.05)$. The highest infit obtained by an item was 1.40 and highest outfit was 6.25. This outfit value is of concern and for this reason an individualized analysis was performed for each item. The item with the highest outfit refers to the word bola [ball] and was the only one that presented a severe misfit, indicating that children with high-level skills wrote this word incorrectly. Finally, the items' reliability index was 0.99 .

In the case of the pseudowords subtest, the items' infit and outfit means were 1.00 $(S D=0.8)$ and $0.97(S D=0.12)$, respectively. The minimum infit was 0.84 and maximum was 1.14. Outfit values ranged from 0.70 to 1.21 and the reliability index was 0.98 . All indexes of this subtest were satisfactory.

\section{Ethical procedures and data collection}

Ethical procedures for this study complied with Resolution 510/2016, Brazilian Council of Health and the project was approved under No. 1,421,568. The TAE was applied in small groups in the school precinct on a single day during regular school hours. The children received clarification about the activity and then watched a 1.5-minute video using a Data show projector. Following this, we did the syllables, words and pseudo words dictation exercises, each of which were repeated only once, if necessary. 


\section{Data analysis}

The Rasch model (1960) was used in data analysis. It is a probabilistic model of one parameter, for difficulty of items. The model simultaneously estimates person and items parameters using the maximum likelihood method. Joint estimation is also independent, which permits generalizing estimations concerning the difficulty of items, regardless of the sample used. At the same time, it allows generalizing the estimates of persons, regardless of the set of items to which they responded (Fernandes, Prieto, \& Delgado, 2015).

For it to be possible to use the Rasch model, the empirical data need to fit the model. Such fit indicates that people answered the items as foreseen by the model. In this sense, the model predicts that people with a high skill level will correctly answer more difficult items than those with lower skill levels. Similarly, those with low skill levels more frequently answer easy items correctly and wrongly answer difficult items. The fit reveals discrepancies between what was expected and what was actually obtained.

Fit criteria proposed by Linacre (2002) were adopted in this study, according to which, values between 0.5 and 1.5 reveal few relevant divergences, while values between 1.5 and 2.0 indicate moderate discrepancies. When the indicator exceeds 2.0, discrepancies are considered to be aberrant. Values below 0.5 reveal discrepancy is greater than expected; however, such cases may be considered random and, therefore, do not affect the measure. In regard to reliability indexes, values concerning Item Separation Reliability were used. Item Separation Reliability can range from 0 to 1 and indicates the accuracy of items, that is, whether the positions of items and persons on the latent variable scale are replicable (Linacre, 2009).

\section{Results}

The analyses based on the Rasch model generated parameters of the students' skills and difficulty of items. Information concerning the students is initially presented, followed by a Wright map, along with the most difficult items of each subtest. Table 1 presents information concerning total scores, students' skills (Rasch measure), measurement error and adjustment indicators, and infit and outfit for all subtests. Table 1 presents information regarding the total scores, students' skills (Rasch model), measurement error and fit indicators, and infit and outfit, for all the subtests.

Note that the mean concerning the children's skills was high on the syllables subtest and the minimum and maximum values of skills reveal good variability in the distribution of children on the logit scale. Additionally, fit indicators were satisfactory, according to the criteria proposed by Linacre (2002). The Person Reliability Index was relatively low.

The skills mean obtained for the words subtest was also high, though lower than the mean obtained on the syllables subtest. The minimum and maximum values reveal a much larger distribution of children's skills. Again, satisfactory fit levels were found 
based on the criteria adopted. The reliability index regarding parameters of children's skills was high.

Table I. Summary of children's performance scores on syllable subtests, words, and pseudowords

\begin{tabular}{|c|c|c|c|c|c|}
\hline \multicolumn{6}{|c|}{ Syllable Subtest } \\
\hline & Total score & Measure Rasch & Measurement error & Infit & Outfit \\
\hline Average & 12,3 & $\mathrm{I}, 45$ & 0,74 & $\mathrm{I}, 00$ & $\mathrm{I}, 04$ \\
\hline D.P. & 3,0 & 1,32 & 0,17 & 0,35 & 0,95 \\
\hline Maximum & 16,0 & 3,68 & $\mathrm{I}, 14$ & 2,35 & 9,90 \\
\hline Minimum & $\mathrm{I}, 0$ & $-3,35$ & 0,55 & 0,39 & 0,14 \\
\hline Person Reliability Index & 0,63 & - & - & - & - \\
\hline \multicolumn{6}{|c|}{ Words Subtest } \\
\hline Average & 16,1 & $\mathrm{I}, 02$ & 0,60 & 0,99 & 1,09 \\
\hline D.P. & 5,5 & 1,69 & 0,13 & 0,30 & $\mathrm{I}, \mathrm{II}$ \\
\hline Maximum & 24,0 & 4,33 & 1,12 & 1,93 & 9,90 \\
\hline Minimum & $\mathrm{I}, 0$ & $-4,37$ & 0,49 & 0,47 & 0,08 \\
\hline Person Reliability Index & 0,85 & - & - & - & - \\
\hline \multicolumn{6}{|c|}{ Pseudowords Subtest } \\
\hline Average & 8,3 & $-0,11$ & 0,59 & 1,00 & 0,97 \\
\hline D.P. & 3,4 & 1,13 & 0,11 & 0,20 & 0,32 \\
\hline Maximum & 16,0 & 3,26 & 1,09 & $\mathrm{I}, 64$ & 3,08 \\
\hline Minimum & $\mathrm{I}, 0$ & $-3,11$ & 0,53 & 0,59 & 0,29 \\
\hline Person Reliability Index & 0,70 & - & - & - & - \\
\hline
\end{tabular}

Source: The authors.

The mean obtained for the subtest of pseudowords was slightly less than 0.0 . Minimum and maximum scores show a large distribution of skills. Infit and outfit values were appropriate, according to the criteria established by Linacre (2002), and reliability was also considered appropriate.

Figure 1 presents the Wright maps of items and persons in the three subtests. The left side of each map shows the position of children on the writing skills scale, while the right side shows the positions of items. 
Figure I. Wright maps of the subtests of syllables, words and pseudowords
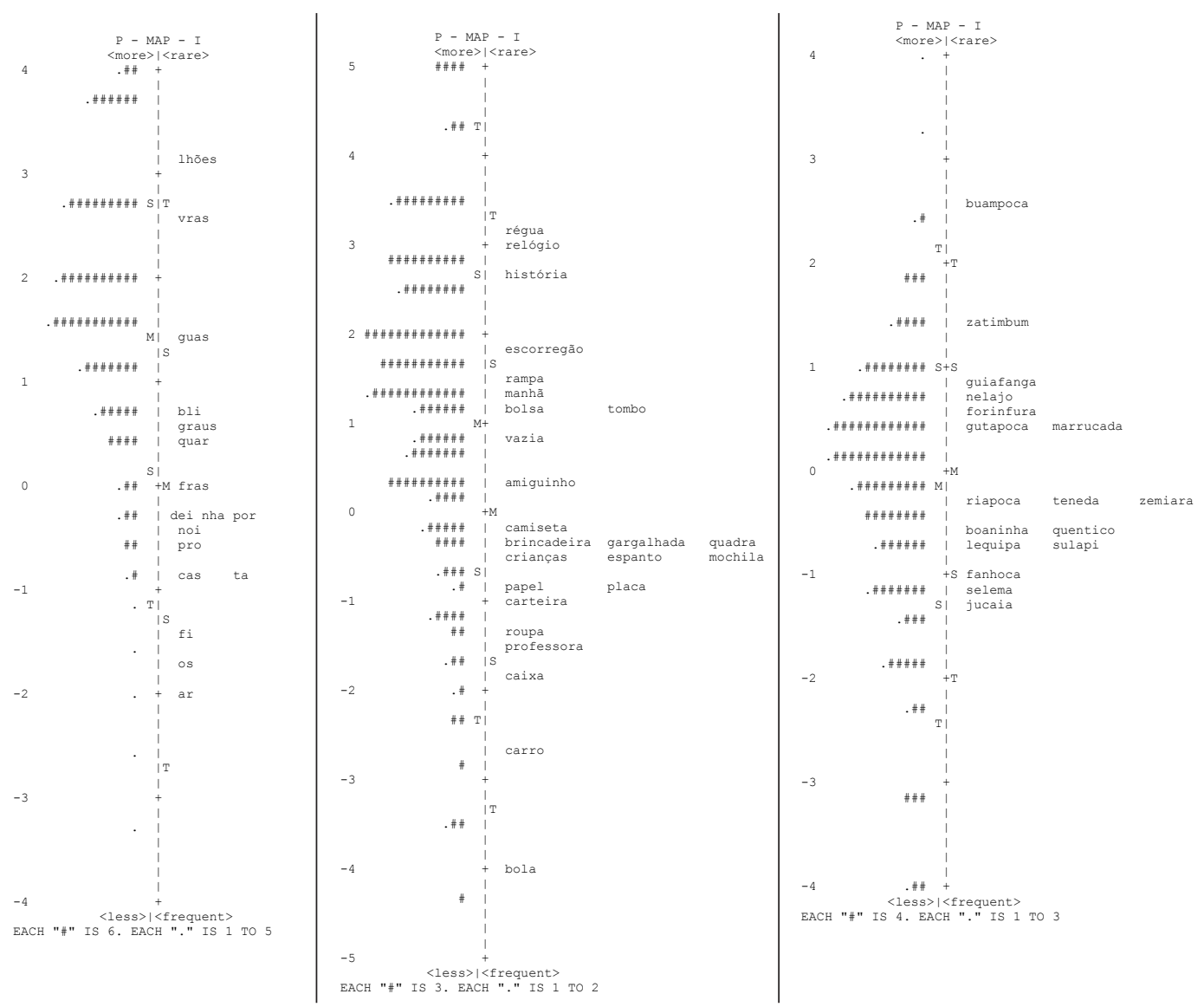

Source: The authors.

Table 2 shows the difficulty level of the most difficult items in each subtest. Also, the values of total score, measurement error, and adjustment are displayed. Also indicated in this table are the difficulty values of the syllables, words, and pseudowwords of the TAE - it is noted that such items were extremely difficult. The measurement and adjustment error values were suitable for all of them. 
Table 2. Indicators of the most difficult items of the subtests

\begin{tabular}{lccccc}
\hline \multicolumn{6}{c}{ Syllables subtest } \\
\hline & Total score & Difficulty & Measurement error & infit & outfit \\
\hline Lhões & 97 & 3,20 & 0,14 & 0,96 & 0,86 \\
Vras & 132 & 2,61 & 0,12 & 1,11 & 1,10 \\
\hline & & Words subtest & & & \\
\hline Régua & 88 & 3,13 & 0,14 & 0,90 & 0,75 \\
Relógio & 92 & 3,05 & 0,14 & 0,96 & 0,81 \\
História & 113 & 2,65 & 0,13 & 0,95 & 1,00 \\
\hline & & Pseudowords subtest & & 0,94 & 0,70 \\
\hline Buampoca & 39 & 2,57 & 0,18 & 1,03 & 0,95 \\
Zatimbum & 94 & 1,37 & 0,13 & \\
\hline
\end{tabular}

Source: Developed by the authors.

\section{Discussion}

This study's objective was to assess and analyze the main linguistic difficulties experienced by students attending from the 2 nd to the 5 th grades using the Rasch model. This model considers the total score sufficient to estimate parameters concerning difficulties for persons and items. Thus, the most difficult items are the ones students most frequently answered incorrectly.

As mentioned in the results, the easiest syllables were those with a vc or cv structure, while Ihões and vras were the most difficult ones. Note that both vras and vraz spellings were considered right as both syllables have a more complex structure (ccvvc and (cvc). In the case of Ihões, there was also the possibility of error due to what Zorzi (1998) called oral support (for instance, liões) or because it allows the representation of nasality by using $\mathrm{m}$ or $\mathrm{n}$ (Ihoens, lioens).

In this sense, Morais (2007) states that the use of forms that represent the nasal sound are a complicating factor when writing skills are being acquired because, in the Portuguese language, the nasal sound can be represented by $m$ or $n$ at the end of a syllable (e.g., bamboo [bamboo] and banda [band], by tilde (manhã [morning]), by the digraph nh (e.g., minha [mine], galinha [chicken]), or by contiguity, in which the following syllable is initiated with a consonant, as is the case of cama [bed], cana [cane], banana [banana] (Caliatto \& Fernandes, 2014). Even though the objective of this study was not to point out the type of errors children most frequently made, based on the aforementioned authors, these were the main possibilities of error for the most difficult syllables. 
Note, however, that in the specific case of the syllable Ihões, due to the various possibilities of error, a more detailed analysis of the most frequent mistakes would be interesting to determine more precisely what the students' difficulties were, in order to devise pedagogical strategies. This initial analysis of the instrument did not indicate any problem with the item construction when fit values are considered. Future analysis, however, might provide a deeper understanding of this item.

As there was no one-to-one correspondence of phonemes-graphemes, students were supposed to be aware that a phoneme can be represented by different graphemes, in addition to having knowledge of orthographic rules and the use of diacritics. The participants' performance on this subtest was inferior to their performance on the syllables subtest, as the means children obtained reveal, which can be visually confirmed on the Wright map.

The results of this subtest reveal that the most difficult words required accents (régua [rule], relógio [watch] and história [history]) but also required the children to master other rules for its correct graphic representation, such as properly choosing between $\mathrm{g}$ or $\mathrm{j}$ in the case of relógio [watch] and using a silent $\mathrm{h}$ at the beginning of the word história [history]. This subtest can be compared to that of the study conducted by Caliatto and Fernandes (2014). They also used the Rasch model to estimate the difficulty level of dictated words and discuss the linguistic complexity presented by the most difficulty words.

Two complications can be considered in terms of the difficulty of the word régua [rule]. First, the use of a diacritic, also considered by Caliatto and Fernandes (2014), as diacritics are required by the most difficult words presented in the dictation. Second, the syllable gua may be another complexity the students faced. The Wright map of the syllables subtest confirms this hypothesis, as it shows that the third most difficult syllable was gua; that is, the students experienced difficulty with this linguistic combination.

In the case of the word história [history], Caliatto and Fernandes (2014) also determined that the most difficult words included those written with the letter $h$ and state that these errors may arise from the fact that, in the case of the word historia [history], $\mathrm{h}$ is silent and its use is irregular. Again, the diacritic may have been an additional complication.

In general, both this study and that conducted by Caliatto and Fernandes (2014) identified some aspects of the Portuguese language that make the acquisition of writing more complex, namely the use of accents and digraphs such as chácara [little farm], burrico [burro], vizinho [neighbor], in addition to sounds that can be represented in more than one way. The difficulty of using digraphs is due to the union of two letters to form a single phoneme (Morais, 2007).

Because the spelling of pseudowords is unknown, it is a task that requires students to convert phonemes into graphemes in their purest form. The fact that students have never been exposed to these words prevents them from recovering previously stored information, forcing them to resort to the process of phoneme-grapheme conversion and to orthographic rules. The students scored the lowest on this subtest. The most 
difficult pseudoword was buampoca followed by zatimbum. Even though we did not analyze the type of mistakes students made, the most apparent difficulties of these pseudowords include the use of well-defined orthographic rules, such as the use of " $m$ " before " $p$ " and " $b$ " and the use of " $z$ " at the beginning of words. Not having being able to properly apply such rules may have led them to misspell these pseudowords. The misuse of rules may have been influenced by the fact that students did not have any mnemonic representation of pseudowords that could support the task.

This study contributed to a deeper understanding of linguistic difficulties contained in words, especially the use of accents, digraphs, nasal sounds, and errors due to multiple spelling possibilities. This type of research provides cues to teachers concerning the potential difficulties students experience in regard to the orthography of the Portuguese language in the alphabetization phase, enabling teachers to foresee difficulties students are likely to face and devise differentiated pedagogical strategies early in the teaching/learning process. This study, however, does not present an analysis of the most common mistakes students made with words that presented more than one possibility for error. In addition to investigating the psychometric properties of the TAE, future studies could also include an analysis of the mistakes made by students.

\section{References}

Batista, A. O., \& Capellini, S. A. (2011). Desempenho ortográfico de escolares do $2^{\circ}$ ao $5^{\circ}$ ano do ensino privado do município de Londrina. Psicologia Argumento, 29(67), 411-425.

Abbott, R. D., \& Berninger, V. W. (1993). Structural equation modeling of relationships among developmental skills and writing skills in primary and intermediate grade writers. Journal of Educational Psychology, 85(3), 478-508.

Caliatto, S. G., \& Fernandes, D. C. (2014). Análise pelo modelo de Rasch do ditado ADAPE: considerações da ortografia. Psico, 45(2), 270-280. doi:https://doi. org/10.15448/1980-8623.2014.2.16820

Capellini, S. A., Amaral, A. C., Oliveira, A. B., Sampaio, M. N., Fusco N., Cervera-Mérida, J. F., \& Ygual-Fernández, A. (2011). Desempenho ortográfico de escolares do $2^{\circ}$ ao $5^{\circ}$ ano do ensino público. Jornal da Sociedade Brasileira de Fonoaudiologia, 23(3), 227-36.

Capovilla, A. G. S., Gutschow, C. R. D., \& Capovilla, F. C. (2004). Habilidades cognitivas que predizem competência de leitura e escrita. Psicologia: teoria e prática, $6(2), 13-26$.

Faraco, C. A. (2016). Escrita e Alfabetização (9 ed.) São Paulo: Contexto.

Fernandes, D. C., Prieto, G., \& Delgado, A. R. (2015). Construção e Análise pelo Modelo de Rasch de Dois Testes Computadorizados de Memória de Reconhecimento. Psicologia: Reflexão e crítica, 28(1), 49-60. doi:10.1590/1678-7153.201528106 
Lemle, M. (2009). Guia teórico do alfabetizador (17 ed.). São Paulo: Ática.

Linacre, J. M. (2002). What do infit and outfit, mean-squared and standardized mean? Rasch Measurement Transactions, 16(2), 878. Retrieved from http://209. 238.26.90/rmt/rmt82a.htm

Linacre, J. M. (2009). A user's guide to WINSTEPS \& MINISTEPS: Rasch Model computers Programs. Chicago, IL: Winsteps.com.

Martinelli, S. C., Caliatto, S. G., Ferreira, A. A., Conceição, A. K., \& Aguena Matsuoka, E. C. (2015). Teste de avaliação da escrita (TAE): proposta de instrumento de avaliação. Comunicaçãooral apresentada no XXII Congreso Internacional de Educación y Aprendizaje. Madri: Universidade CEU San Pablo.

Morais, A. G. (2007). Ortografia: Ensinar e aprender (4 ed.). São Paulo: Ática.

Morais, A. G., \& Rios Leite, T. M. B. S. (2012). A escrita alfabética: por que ela é um sistema notacional e não um código? Como as crianças dela se apropriam? In Brasil, Pacto nacional pela alfabetização na idade certa: a aprendizagem do sistema de escrita alfabética, ano 1: unidade 3 (pp. 8-18). Ministério da Educação, Secretaria de Educação Básica. Brasília: MEC, SEB. Recuperado de http://pacto. mec.gov.br/images/pdf/Formacao/Ano_1_Unidade_3_MIOLO.pdf

Nunes, T., \& Bryant, P. (2014). Leitura e Ortografia: além dos primeiros passos. Porto Alegre: Penso.

Rasch, G. (1960). Probabilistic models for some intelligence and attainment tests. Copenhagen, Danmarks: Danmarks Paedagogiske Institut.

Rosa Neto, F., Xavier, R. F. C., \& Santos, A. P. M. (2013). Caracterização da leitura e escrita. CEFAC, 15(6), 1643-1653. doi:https://doi.org/10.1590/S1516-18462013005 000013

Santos, M. J., \& Maluf, M. R. (2010). Consciência fonológica e linguagem escrita: efeito de um programa de intervenção. Educar em Revista, 38, 57-71. doi:https:// doi.org/10.1590/S0104-40602010000300005

Vega Cuetos, F., SÁnchez Ramos, J. L., \& Hernandez Ruano, E. (2002). Evaluación de procesos de escritura (PROESC). Madri: Tea ediciones.

Zorzi, J. L. (1998). Aprender a escrever: a apropriação do sistema ortográfico. Porto Alegre: Artes Médicas.

Submission: 1.6.2016

Acceptance: 1.11.2017 